\title{
The ethical-political dimension of social and community praxis: The case of Ecuador's early response to covid-19
}

\author{
Manuel Capella \\ Faculty of Psychological Sciences, University of Guayaquil, Ecuador
}

\begin{abstract}
In Ecuador, the painful impact of the covid-19 pandemic elicited early responses by the government, and by local communities. This critical, positioned and exploratory case study analyses such responses, underscoring the fundamental ethical-political dimension of any academic and professional praxis aimed at the construction of healthier societies worldwide. While critical traditions are familiar with this stance, the inequalities and ideological mechanisms made visible by covid-19 responses may enable the wider community of researchers and practitioners to join ongoing collective ethical-political efforts. Findings from Ecuador underline the potentially harmful role of neoliberalism, and issues of democratic legitimacy; significant problems before and during the pandemic shock; and official discourses which blame communities for their own suffering and death. Neutrality and depoliticized notions of scientific evidence are notoriously insufficient in these scenarios. We need to engage more deeply with diverse forms of global and local community resistance, in times of covid-19, and beyond. Please refer to the Supplementary Material section to find this article's Community and Social Impact Statement
\end{abstract}

Keywords: covid-19; critical community psychology; liberation psychology; Latin America; Ecuador

\section{Introduction}

COVID-19 has exposed structural inequality across the world, which begs us to reinvigorate our ethical-political engagement as academics and practitioners. Such engagement is not at all new to most community psychologists; many of 
them, inspired by a Latin American tradition that calls for psychological and political "liberation" (Martin-Baró, 1994; Montero, Sonn, \& Burton, 2017). However, as examined in Latin America, efforts towards liberation in neoliberal contexts face structural and ideological limitations, which requires an intensification of our ethical-political positions (e.g., Barrero, 2020; Berroeta, Reyes, Olivares, Winkler, \& Prilleltensky, 2019; Capella \& Jadhav, 2020; Grondona-Opazo \& Rodríguez, 2020). In pandemic times, this challenge seems to be as urgent as ever. Not only for community psychologists, but for all social scientist and practitioners.

This paper focuses on Ecuador, a South American nation with notorious problems during the early response to covid-19 (Benítez et al., 2020). It is too obvious to simply state that the pandemic's devastation in Ecuador is a question of "fragile and often unprepared systems in developing countries" (Hallo, Rojas, \& Hallo, 2020 , p. e7452). We need to go further, and critically examine the underlying structures and particular processes which resulted in such fragility.

Globally, social scientists' early responses to the pandemic were fast-tracked research and literature reviews (e.g., Van Bavel et al., 2020). Despite of this, some governments - including the Ecuadorian - have failed to prevent unnecessary suffering and death. Their failure reflects inequalities in class, gender and race-ethnicity, which the pandemic have made strikingly visible in both richer nations (e.g., Marmot, 2020) and poorer nations (e.g., MackworthYoung et al., 2020). Evidence-based responses to COVID-19 are not expected to succeed unless inequality is addressed, through the active participation of 
communities most affected by it (Burgess, 2020; Burgees et al., 2021; Ntontis \& Rocha, 2020).

It seems that some politicians are unable or unwilling to follow the "evidence" regarding inequality and community participation. However, it also seems that we need to question if we are approaching the notion of evidence with enough psychopolitical validity (Berroeta et al., 2019; Fine, 2012). It may not be enough to inform policy with our knowledge claims regarding communities and social processes. We actually need to stop being "afraid to engage with the politics" (Patel, 2020, p. 1694).

The non-neutral nature of evidence is not an exclusive invention of critical community psychologists. We know about it from classic formulations in sociology of science (Berger \& Luckmann, 1967); contemporary arguments in philosophy of science addressing psychology (Talak, 2014), policy research and public health (Breilh, 2008; Greenhalgh \& Russell, 2009; Patel, 2020); critical medical anthropology (Erikson, 2020); and other cross-disciplinary endeavours. Science is not "apolitical and indisputable" (Stevens, 2020, p. 41562). It is a social praxis that exists within certain power relationships. The Ecuadorian case underscores the complex ethical-political challenges this entails in particular settings.

\section{Methods}

The selected method was that of a case study, which allows for an in-depth particularistic examination (Harrison et al., 2017). My exploratory analysis 
focused on the governmental response to COVID-19 in Ecuador, from 29 January 2020 until 25 May 2020; as well as preliminary elaborations regarding the community response. This time frame begins with the World Health Organisation's declaration of the pandemic, and ends with the eruptions of protests across Ecuador, contesting the government's response to the health crisis (protests which have decreased for the time being).

I gathered and analysed data while in confinement myself, recurring mainly to digital social media and online browsing. Sources were purposively selected, based on unstructured observations, with the intention of approaching an exploration of context, lived experience, and critical considerations regarding power. Such methodological strategy is consistent with several qualitative traditions, including that of critical ethnography (Madison, 2019), in this case, based on digital fieldwork (Góralska, 2020). I partially incorporated some of the embodied reflexivity that is common in autoethnography; however, the focus of the findings reported here is not autobiographical, but context-oriented.

I consulted several sources, including fourteen that have a specific focus on the Ecuadorian case: public addresses by the national government, watched on television and then revisited (i.e., Ecuador TV, 2020a; 2020b; 2020c; 2020d); reports by journalists and citizens focused on Ecuador's initial health and funerary crisis, and some of the local community responses to it (e.g., Channel 4 News, 2020; El Comercio, 2020; El Universo, 2020, among others); and a few academic publications - also with such a focus - retrieved through exploratory searches (e.g., Badillo \& Fisher, 2020; Benítez et al., 2020; CEDATOS / GALLUP 
International / WIA , 2020; Click Research, 2020; Hallo, Rojas \& Hallo, 2020; Long, 2020; Moser \& Pick, 2020).

I interpreted some issues worth examining, when contrasting these different sources. Being a critical social scientist and practitioner myself, I made a particularly problematic observation, which became the criteria to what issues deserved further unpacking: while many well-intended academics attempted to provide scientific evidence to the government (and to part of the population: e.g., through social media), the power dynamics shaping life and death in Ecuador seemed to transcend such instrumental and - in many cases - apparently depoliticized approach. This concern motivated and guided the analytical process.

My exploratory analysis of textual data was partially inspired by elements of critical discourse analysis (Fairgclough, 2013). The immediacy of examined events, as well as time constraints and other limitations inherent to confinement, made it difficult to expand the analysis beyond its exploratory scope. Following Fairclough (2013), analytical themes focused on ideology and power asymmetries, identifying a social wrong; some mechanisms that sustain it; and potential strategies for resistance. Analysis was inductive, with no formal use of higher level themes; however, oppression and resistance were implicit guiding notions, approached from the author's own critical positionality (Montero et al., 2017).

Discourse itself was not an isolated focus of inquiry, but considered in relation to meta-textual elements (i.e., actual events that took place in the country vis-à-visthe governmental discourse). I observed and analysed the material a priori. I then 
revisited it while taking analytical notes that gradually expanded and deepened, in order to build the argument presented in this paper. Findings are reported in a way that articulates descriptive and interpretative accounts, constructed by the author in relation to context, lived experience, as well as positioned and situated readings of these. Thus, conclusions from this exploratory case study are not meant to be acritically generalised.

\section{Findings}

Findings are organised into two broad themes: early responses by the Ecuadorian government; and factual and possible responses by local communities.

\section{The government's response}

To understand the government's response to the pandemic, we must first consider the recent political context that shaped it.

\section{Before the pandemic: neoliberalism and democratic legitimacy}

After more than twenty years shaped mostly by neoliberal administrations, a political project known as the "citizen's revolution" governed the country in the past decade (2007 - 2017). Despite many shortcomings and legitimate critiques, official statistics suggest this process achieved "remarkable political, social, and 
economic progress" (Wolff, 2018, p. 298), including increasing public health investment. After a tight and polarised election, such project was voted to continue (2017-2021). However, immediately after taking power, the elected president-and former vice-president (2007 - 2014) — Lenín Moreno declared his opposition to the preceding administration, accusing them of alleged corruption, authoritarianism and overspending of public funds.

Moreno shifted towards a neoliberal agenda with scant democratic legitimacy. Austerity measures, polemic institutional reforms and legal actions, and the appointment of officials alien to the project elected in the polls (including a substitute vice-president). Economic indicators worsened, and inequality increased (INEC, 2020, p. 6); Public health investment decreased, and thousands of public health staff were laid off. The administration signed a deal with the International Monetary Fund, which is expected to deepen inequalityincluding healthcare access-and affect democracy (Forster, Kentikelenis, Reinsberg, Stubbs, \& King, 2019). This seems to have shaped the shortcomings in Ecuador's COVID-19 response (Badillo \& Fischer, 2020; Benítez et al., 2020).

On October 2019, the Ecuadorian government announced austerity measures that would increase fuel prices. In turn, mass protests arose. Urban and rural communities participated, as well as diverse political factions, ultimately led by a powerful indigenous movement. The Government answered with repression. Officially, there were at least 9 dead reported at the time, over fifteen hundred injured - some severely - and over one thousand jailed—many arbitrarily (UN News, 2019). Several human rights were violated by the government, as documented in numerous cases (Comisión Especial para la Verdad y la Justicia, 
2021). After eleven days, the government negotiated with indigenous leaders and temporarily annulled the austerity measures. Protest demands included changes in policy-making, as well all the resignation of State Officials partly responsible for the crisis. None of this occurred at the time. The government blamed the protests to the influence of the previous administration, accusing them of utilising "fake news" and other strategies for political destabilisation.

Moreno's approval was at $20-22 \%$ before the protests; $12 \%$ during the protests, the lowest in Ecuadorian history; and later returned to its previous level (Notimundo, 2019).

\section{Shortcomings during the alarm phase}

The government underestimated the threat during the alarm phase of the health emergency (Badillo \& Fischer, 2020; Long, 2020). In February, the vice-president joked about travelling to China and catching the virus. Epidemiological control at Guayaquil's airport was first absent, and then minimal. Many incoming travellers - including several wealthy subjects returning from vacations in Europe - seemed to have been positive for COVID-19, but entered the city unidentified. Some of them - such as the "index" patient officially identified on 29 February - had numerous physical interactions with others, including health staff. Massive events were allowed. The governor of the Guayas Province even promoted a football match in Guayaquil on 4 March, saying people should not fear the virus; almost 20k people attended. 
On 11 March, a state of national health emergency was declared; and on 13 March, a Special Committee was formed to deal with the crisis. By that time, the virus had already spread violently across Guayaquil, the poorest and more unequal city in Ecuador (INEC, 2020).

\section{The horror of the shock phase}

After the pandemic hit, the response by the Ecuadorian government was notoriously insufficient, causing massive suffering. This becomes quite visible when compared to other nations in the region, such as Brazil, Colombia, Bolivia and Peru. According to Benítez et al. (2020), out of the five countries, Ecuador made the least amount of timely and reliable covid-19 tests; had very limited intensive care unit capacity; made the shortest early efforts to allocate emergency health funds; took around two weeks to deliver a set number of food kits; failed to provide timely and adequate support to informal workers; and failed to engage in tax and financial interest relief. It seems that Ecuador had the largest death toll during the first months of the crisis (both per population; and per confirmed positive cases) (Benítez et al, 2020). During the early stage, most of the over 30k excess deaths occurred in the Guayas province, and its capital, Guayaquil.

The health and funerary systems collapsed in Guayaquil. Thousands fell ill with no chance of being admitted into a hospital; health supplies, medicine and biosafety supplies were scarce and difficult to access. An emergency phone line was activated by the central government. Thousands struggled to put food on their table. In words of an interviewed man cuing outside a cemetery with the 
coffin of his deceased mother: "this is how we Ecuadorians are living. No one represents us, we are alone" (Channel 4 News, 2020) [Channel 4 News translated "nadie nos representa" as "no-one cares about us"; my translation of "representa" is "represents"]. Media pictures and videos displayed painful realities of dead bodies found in households, hospital storage rooms, and on the street. Days later, a special task was formed for funerary assistance. Due to inefficient and inhumane governmental management, over one hundred grieving families from Guayaquil struggle to find the bodies of their love ones, in many cases, even to this day.

Visible leadership from Guayaquil's municipal government appeared to be rather absent during the first weeks of the emergency. A peculiar event occurred on 17 March, when the Mayor of Guayaquil gave orders to physically stop a humanitarian flight - coming from Spain with only crew on board - from landing at the city airport. The mayor argued the decision was made to protect the city; two days later, she announced being positive for COVID-19 and isolated at home. City hall cooperated with local resources and the management of private donations - including a contentious donation of 1000 cardboard coffins for the poor. A telepsychology service was also activated by late March, which added up to the helpline provided by the central government.

The Ecuadorian administration - with insufficient resources to care for its population - paid 341M USD (including interests) to private bonus holders on 24 March; other diverse transfers to foreign organisations may have amounted to roughly one billion USD. During May - as quarantine gradually relaxed -, the Ecuadorian government continued "optimising" (i.e. reducing) budgets for public 
health and education, laying off thousands of teachers and health staff. It also seized the moment of shock to reimpose the undemocractic austerity measures regarding fuel prices which caused the October 2019 protests. Alarming cases of public-private corruption around the acquisition of health supplies and food kits are still being investigated.

Under the circumstances described so far, it was no surprise that the majority of the population did not trust official political leaders' response during the crisis (CEDATOS / GALLUP International / WIA, 2020; Click Research, 2020; Long, 2020). For example, the way President Moreno managed the crisis only had an approval of $18-24 \%$; and the way Guayaquil's Mayor managed it had only a $32 \%$ approval. Distrust in politics is not the issue per se, but in this case it is rather indicative of underlying issues: structural inequality and the needs of the majority which have not been met by political action.

The response by the government did include some valuable efforts. Specially in terms of post-shock confinement, and significantly less in terms of effective and timely prevention and mitigation (Benítez et al., 2020). I hypothesise there must have been at least partial attempts to be informed by "evidence" (e.g.,the promotion of a shared social identity, denunciation of "fake news", and provision of some psychological support, Van Vabel et al., 2020). The government's narrative focused on the need to trust the administration, unite and cooperate, while praising their response to the crisis and framing it as an accomplishment (Ecuador TV, 2020a).

Even prior to the pandemic, the Ecuadorian government claims to have based their decisions on "reason", "peace", "dialogue" and "democracy", rejecting 
"authoritarianism" and "populism" (Ecuador TV, 2020a). However, the previously reported accounts seem to differ from such rhetoric. This is not simply a problem of leadership and trust-insofar as one might abstract them as isolated, analytical categories-but a fundamental problem of democratic legitimacy. It is a significant ethical-political challenge for social scientists to assist the government in these particular circumstances.

\section{Official discourse and the pathologisation of community}

The Ecuadorian government denies any charge of significant negligence. In fact, President Moreno has congratulated his governmental team for their hard work, and mistakenly claimed Ecuador had one of the most efficient responses to the pandemic in the region (Ecuador TV, 2020a, 2020c). The vice-president only apologised for "images that never should had happened", which "deteriorated" Ecuador's international reputation, after weeks of public pressure by local communities (Ecuador TV, 2020b). President Moreno then justified the errors made: "of course we were not prepared", as "no one was"—referring to citizens, corporations and other countries-and alleged the government had "made corrections along the way" (Ecuador TV, 2020c).

Official discourse on the local devastation wrought by COVID-19 thus seems to orbit around two main arguments: blaming the previous administration, and blaming local communities. The first had been a constant rhetorical strategy since

President Moreno took power. The second requires further elaboration, as it seems to frame the community as the main culprit in the spread of the virus. (Ecuador TV, 2020b, 2020c, 2020d, 2020a). 
The President had threatened those who disobey government regulations with firm sanctions. The vice-president explained how "the difference between life and death is in our discipline. We will only overcome this with order and respect for authority" (Ecuador TV, 2020d). He explained that "what happened in Guayaquil is a sad exception of what has given us better results in the rest of the country" (Ecuador TV, 2020d); and said to be working for the benefit of everyone, including "those who disobey norms or insult us" (Ecuador TV, 2020d). Notice the implicit notion of "us" (the government), versus "them" (communities). He also minimised the role of inequality: "this crisis is not about left and right, rich and poor, and this virus does not see religion, race or social strata. It only seeks to propagate" (Ecuador TV, 2020b).

In contrast with such allegedly class-blind rhetoric, it was mostly working class men and women who put themselves at higher risk in order to secure basic hygiene, food and medicines for themselves and others. Part of the population indeed disobeyed norms in Guayaquil; understandable to a significant extent, as many there survive on precarious labour and lack other means to comply. Yet the wealthy also disobeyed: police officers raided a golf match and at least two luxurious wedding parties. On March 22nd, Guayas was declared a "special safety zone": direct military control of the area to ensure obedience to regulations. A few images on social media denounced soldiers in deprived neighbourhoods not in wealthy areas-humiliating curfew offenders with haircuts or physical exercise. Despite the government's sensationalisation of these offenders, it is reasonable to hypothesise that most citizens who could did stay at home. 
An excessive focus on alleged psychological and cultural flaws of local - mainly low-income - communities diverts attention from other determinant issues (see previous sections). For example, on April 1st, a rumour of a full lockdown-which never occurred-was spread by the Guayas governor (the same individual who promoted football matches during the alarm phase), causing unusually high lumping of groups in banks and grocery stores. Media can thus reinforce such pathologisation of local communities by: erasing or underreporting the negligence of political leaders; uncritically rehashing official discourse; and framing social issues as individual problems. In the latter's case, the media reported on "psychologists" and "coaches" who argued that the tragic outcome of the crisisunnecessary deaths exacerbated by political decisions-is an "opportunity for growth" (El Universo, 2020).

\section{The community response}

Given the novelty of the recent events, the specific ways through which local collectives have resisted the pandemic shock and its aftermath are still being researched. We do know that most communities - especially those most affected by structural inequality, recent neoliberal policy, and anti-democratic governance -, do not trust the Ecuadorian government. We know that, to a significant extent, the official discourse by the government made communities almost entirely responsible for their own suffering and death; when, in reality, there were many structural factors - mainly poverty and inequality - which limited their agency, 
especially for those who have been historically excluded (Capella, Jadhav, \& Moncrieff, 2020).

Here, I want to refer to one particular community, as it is central to the argument of this paper: the community of researchers and practitioners interested in subjective and social phenomena. As expected, many members of such community remained inactive; shocked by the tragic events we were living, or focused on more orthodox, allegedly apolitical approaches to scientific and professional praxis. However, three years of governmental actions worsening social inequality has led many of us to try to embrace ethical-political engagements during the covid-19 crisis, in diverse ways. These included, at least, two non-exclusive strategies: protesting and demanding rights; and participating in bottom-up instrumental community solidarity.

Protesting is a basic human right. Even when protests evidently increase health risks, they seem to be a legitimate - and arguably necessary - action. The massive anti-austerity protests of October 2019 in Ecuador, for example, were actively supported by hundreds of academics, some of whom stood side by side with local communities on the streets, breathing the same tear-gas thrown by the police $^{1}$ (myself included). On the $25^{\text {th }}$ of May, 2020, thousands of protestors hit the streets again, risking their lives and those of their loved ones, desperate to grieve for the dead, to denounce the government's response to the pandemic, and to repudiate cuts in public health and education. Though these protests promoted several measures to stay safe (e.g., keeping physical distance, wearing

\footnotetext{
${ }^{1}$ Ongoing investigations have identified the dangerous use of expired tear gas by the police
} 
masks), the government associated this public outcry with political parties seeking "chaos", and warned that "the full weight of the law" would fall upon protestors if they break health regulations (EI Comercio, 2020).

Protests can also take digital forms. Many of them are capillary everyday digital practices (Capella, 2020). Despite the risk of manipulative content -which, at least in Ecuador, may come from both non-official and official sources -social media have been a major space to protest injustice and demand rights. It is also, a key tool for globalising ethical-political projects based on a diversity of local realities with shared concerns. In turn, however, the government decried social media as a source of "fake news", and accused the previous administration for their involvement in this.

Inspiring bottom-up initiatives of solidarity arose in Ecuador nonetheless. Some were actually linked to the demand of rights to the State through legal means and direct democracy, as well as the proposing of emergent alternative strategies to the authorities. Others focused on mutual help regarding food and health, led by organised famers, volunteers in partnership with coastal indigenous communities, autonomous urban workers, and alliances of urban neighbourhoods. Citizens developed apps and digital spaces for mutual help, including that related to food and health, as well as barter. A manifesto against structural racism (including lack of culturally-sensitive official data) was produced by feminist and African-descendant collectives (Colectivo Reexistencias Cimarrunas, Mujeres de Asfalto, y AMANDLA, 2020). In these, and other cases, the role of local families was pivotal (Moser \& Peek, 2020). 
Several academics supported or volunteered in some of these community initiatives. Others, like critical geographers, utilised cartography to visualise them (https://www.rosalux.org.ec/solidaridad-covid19/). While such engagements are necessary, two points of caution must be made. First, it is important to scrutinise possible ulterior agendas of some performers, particularly on initiatives associated with mainstream political and financial power. Secondly, it is necessary to remain aware that exclusive efforts for grassroots mobilisation indeed bolster the government's evasion of accountability and instead blame local communities for their lacking of empowerment. President Moreno, for example, actually highlighted the role of communities' "values", and their "responsibility" for their own health regarding COVID-19 (Ecuador TV, 2020a).

\section{Discussion}

If we contrast the Ecuadorian case with the literature reviewed by Van Bavel et al. (2020), it becomes clear that the official response in Ecuador was affected by issues of inequality, underestimation of threat, distrust, inadequate leadership and deficient public communication. Contrary to the official rhetoric by the Ecuadorian vice-president - which implied that COVID-19 is blind to class and race-ethnicity (Ecuador TV, 2020b) - the virus "revealed deep inequalities", particularly in Guayaquil (Moser \& Peek, 2020). Understandably, trust in the government have been broken; and without genuine democracy, trust and mutual respect, adequate health care is unviable (Napier et al., 2014). 
Many recent events illustrate some of these alarming issues regarding inequality, distrust and inadequate leadership in Ecuador. Among them, one seems to be particularly shocking. In March 2021, the president admitted that there was no structured vaccination plan in the country (CNN, 2021). He made such claim, despite the fact that the vaccination process started two months ago, after a small batch of covid-19 vaccines arrived in the country (CNN, 2021). More alarmingly, social media - and then traditional media (CNN, 2021) - exposed cases of a few people with higher economic and social capital accessing the government's vaccination process with little transparency, while the overwhelming majority of local communities waited to get the shot.

A different event also seems to beg further critical inquiry: the way Guayaquil's Municipal government have been promoting and utilising ivermectin - an antiparasitic drug - to prevent and/or treat covid-19, without having sufficient evidence on its effects. More recently, the World Health Organisation recommended against the use of ivermectin for the general population.

To put the spotlight on the government - instead of communities - can be interpret as a form of "backwards" community psychology (Wiesenfeld, 2016). This is, a relative subversion of power relationships by examining, not problems of communities in alleged deficit, but problems of official power called to guarantee the rights of those communities. This is, to look deeper into the roots of a system that was "underprepared" to care for its population (Hallo et al., 2020).

We knew about the importance of ethical-political engagement for social change way before covid-19 hit us (Martin-Baró, 1994; Montero et al., 2017); as we faced difficulties moving from "assistance" towards a deeper "transformation" (Berroeta 
et al., 2019, p. 292). Responses to the pandemic had made this challenge much more difficult to ignore; well-intended initiatives such as individualist telepsychology seem insufficient (Burgess, 2020; Capella, 2020). Claiming an illusory evidence-based scientific neutrality can contribute to sustaining academic ivory towers disconnected from the political struggles of historically oppressed communities. Specially in countries that lack "respected politicians" who are effective, transparent and in-tune with public motivations (Van Bavel et al., 2020, p. 16); or if presidents display "incompetence" (Marmot, 2020, p. 1413).

Is it necessary to inform policy-makers with "evidence"? Yes. Is it enough? Certainly not, as in conditions as those described here, our efforts will be "severely compromised" (Ntontis \& Rocha, 2020, p. 105). We need a positioned construction of evidence and practice, addressing "the sprawling historic and contemporary stretches of injustice and contestation; the circuits that link privilege and marginality; structures, histories and lives; dispossession and resistance" (Fine, 2012, p. 14). Not instrumental, disembodied and depoliticized social engineering.

We need a deeper and reinvigorated ethical-political engagement with social change, through both material and symbolic means (Campbell, 2013; PavónCuéllar, 2020). One alternative is to embrace prefigurative action: examining the contextual limitations of our work, and engage as allies and co-learners with marginalised communities and social movements (Kagan, Burton, Duckett, Lawthom, \& Siddiquee, 2019). An alternative, at the opposite end, would be to contribute through patch-work solutions focused on compliance/adherence, manipulating public opinion into having a more positive attitude towards the 
government despite their politic. These are just two polar alternatives, among many other. We all need to decide how to deal this ethical-political challenge, based on our ideas, values, capital, possible risks, strengths and limitations.

The understanding and engagement with communities is key in this complex scenario in, at least, two senses.

Firstly, we could learn from governments working alongside communities in diverse settings around the world, as well as from collective actions of solidarity and resistance (Ntontis \& Rocha, 2020). Academics and professionals may have something valuable to teach communities, but commnities certainly have plenty to teach us. For example, we could explore the role of communities in what the labour party accomplished in New Zealand, or what a leftist coalition accomplished in Kerala, India (Varghese, 2020). We could learn how communities resist scarcity of resources in Africa (Mackworth-Young et al., 2020); and Latin American Zapatista communities may inspire us with their praxis of conviviality and radical approach to care (Callahan, 2020). An in-depth examination of these and other examples transcends the scope of this paper, but constitutes an urgent task at a global scale.

Secondly, we may need to consider engaging in unveilling the dominant ideology (Martín-Baró, 1994). There are many discourses that need to be de-ideologised in pandemic times. The idea that covid-19 affects everyone equally, causing deaths which are always inevitable. The idea that commnuties suffer and die exclusively because of their flaws, not because of structural limitations which constrain their "ability to comply with lockdown regulations" (Jetten et al., 2020, p. 13). "Small-government ideologies" (Marmot, 2020), which "leave too much 
health preparedness to 'the market', creating a perfect storm" (Erikson, 2020, p. 441). The capitalisation of moments of "shock" to impose undemocratic austerity policies (Klein, 2007). The pathologisation and blaming of entire communities (Napier et al., 2014), which politicians can use for advancing unethical agendas during the pandemic (Drury, Reicher, \& Stott, 2020).

Scientific discourses require reflexivity regarding their relationship with ideology. For example, it is true that polarisation can lead to mutual distrust (Van Bavel et al., 2020). However, readings of the concept which demonise committed ethicalpolitical positions "ensure that 'social psychology' and 'political psychology' are evacuated of any social and political content, so that questions of power, conflict and change are turned into questions only of psychology" (Parker, 2007, p. 97). To discuss individual "healthy mindsets" and dangerous "fake news" may be necessary in certain contexts (Van Bavel et al, 2020). Yet, it could also be utilised to underplay the struggle for healthy societies; and the role of social media as complex platforms for resistance.

The Ecuadorian case illustrates quite well many of the ideological mechanisms mentioned so far. The task to unveil ideology can be challenging, especially in times where global priorities are legitimately centred on tangible, life-saving technologies (e.g., vaccines; medical treatment; instrumentally applied social sciences). Priorities that include, for example, valuable recommendations by social scientists on pathways to advance "community engagement" in the context of national vaccination plans, highlighting key issues such as diversity, vulnerability, trust and power (Burgess et al., 2020). While life-saving priorities are evidently urgent, it is important to bear in mind that ideology also costs lives 
by sustaining unhealthy structures and undermining the accountability of those in power, who may or not listen to academics depending on political, economic and cultural positions and agendas.

We need to take a slower, more sustainable approach to the aftermath of COVID19; one that transcends instrumental contingencies. This requires deeper reflections regarding subjectivity and power (Barrero, 2020; Dusell, 2020; The Rising Majority, 2020; Žižek, 2020); and our ideological positioning as social scientists (Flores, Huerta-Charles y Bravo, 2020). The search for truths should not only be "an account of what has been done, but of what needs to be done" (Martin-Baró, 1994, p. 23). This is an ethical-political question, that begs an ethical-political response from all social scientists and practitioners who seek to collaborate in the construction of healthier societies.

\section{Conclusions}

The Ecuadorian case highlights the need to reinvigorate our ethical-political positions as academics and professionals, in times of covid-19, and beyond. This challenging task implies a serious consideration of context, democratic legitimacy and the risks of neoliberal governance; unveiling the ideology behind official discourses which blame communities for their suffering and death; and making efforts to understand, amplify, and contribute with, ongoing bottom-up collective actions to resist, and construct more equal societies that foster wellbeing for the majority of the world. 
This agenda is as necessary as ever in current times. Ethical-political engagement can take many forms, depending on individual and collective agencies, vis-à-vis structural constrains. Research endeavours must include significantly deeper ethical-political engagement, ideally, by assuming the role of allies and co-learners alongside marginalised communities and social movements in the struggle for social change. This urgent need is not limited to the purview of critical, political or community psychologists alone, as one might assume. Rather, it is a call for all social scientists and practitioners. The challenge is massive, and the invitation to join the struggle of so many people across the globe remains as valid and urgent as ever for all of us.

\section{References}

Badillo, A. L., \& Fischer, A. M. (2020). Ecuador, covid-19 and the IMF: How austerity exacerbated the crisis. Retrieved from https://issblog.nl/2020/04/09/covid-19-ecuador-covid-19-and-the-imf-howausterity-exacerbated-the-crisis-by-ana-Iucia-badillo-salgado-and-andrewm-fischer/

Barrero, E. (2020). Clínica psicopolítica. Aportes para la construcción de una psicología de la subversión en tiempo del horror neoliberal [Psychopolitical clinic. Contributions to the construction of a subversive psychology in times of neoliberal horror]. Bogotá: Ediciones Cátedra Libre.

Benítez, M. A., Velasco, C., Sequeira, A. R., Henríquez, J., Menezes, F. M., \& Paolucci, F. (2020). Responses to covid-19 in five Latin American countries. Health Policy and Technology, 9(4), 425-559.

https://doi.org/10.1016/j.hlpt.2020.08.014

Berger, P. L., \& Luckmann, T. (1967). The social construction of reality: A treatise in the sociology of knowledge. New York, NY: Doubleday.

Berroeta, H., Reyes, M., Olivares, B., Winkler, M., \& Prilleltensky, I. (2019). Psicología comunitaria, programas sociales y neoliberalismo: la experiencia chilena [Community Psychology, social programes and neoliberalism: the Chilenean experience]. International Journal of Psychology, 53(2), 281-297. 
Breilh, J. (2008). Latin American critical ('social') epidemiology: New settings for an old dream. International Journal of Epidemiology, 37, 745-750.

Burgess, R. (2021). COVID-19 mental-health responses neglect social realities. Nature World View. https://doi.org/doi: 10.1038/d41586-020-01313-9

Burgess, R., Orborne, R., Yongabi, K., Greenhalgh, T., Gurdasani, D., Kang, G., Falade, A., Odone, A., Busse, R., Martin-Moreno, J., Reicher, S. \& McKee, M. (2020). The COVID-19 vaccines rush: participatory community engagement matters more than ever. The Lancet, 397(10268), 8 - 10 https://doi.org/10.1016/S0140-6736(20)32642-8

Callahan, M. (2020). [COVID-19] (insubordinate) conviviality in the covid-19 conjuncture. Retrieved from

https://www.convivialthinking.org/index.php/2020/04/24/insubordinateconvi viality/

Campbell, C. (2013). Community mobilisation in the 21st century : Updating our theory of social change? Jounal of Health Psychology, 19(1), 46-59. https://doi.org/10.1177/1359105313500262

Cepella, M. (2020). Corpses in the street, psychologist on the phone: Telepsychology, neoliberalism and Covid-19 in Ecuador. Somatosphere. Retrieved from: http://somatosphere.net/2020/telepsychologyneoliberalism-and-covid-19-in-ecuador.html/

Capella, M., \& Jadhav, S. (2020). How coloniality shapes the making of Latin American psychologists: Ethnographic evidence from Ecuador. International Review of Psychiatry, 32(4), 348-358. https://doi.org/10.1080/09540261.2020.1761777

Capella, M., Jadhav, S., \& Moncrieff, J. (2020). Violence, history and collective memory: Implications for mental health in Ecuador. Transcultural Psychiatry, 57(1), 32-43. https://doi.org/10.1177/1363461519834377

CEDATOS / GALLUP International / WIA. (2020). CEDATOS: el covid-19 cambió la vida y expectativas de los ecuatorianos. apreciaciones de la población al 16 de abril de 2020 [CEDATOS: covid-19 changed the life and expectations of Ecuadorians: views by the population, 16th April 2020]. Retrieved from https://www.cedatos.com.ec/blog/2020/04/18/cedatos-elcovid-19-cambio-la-vida-y-expectativas-de-los-ecuatorianos-apreciacionesde-la-poblacion-al-16-de-abril-de-2020/

Channel 4 News. (2020). Bodies left in streets of Guayaquil as Ecuador struggles with coronavirus [video file]. Retrieved from https://www.youtube.com/watch?v=XHsfjnRB-uA

CNN (2021). Lenín Moreno culpa a su ministro de salud por no tener un plan de vacunación contra el covid-19 [Lenín Moreno blames his health minister for not having a covid-19 vaccination plan] [video file]. Retrieved from: 
https://cnnespanol.cnn.com/video/moreno-plan-de-vacunacion-estaba-enla-cabeza-del-ministro/

Click Research. (2020). Click report. no hay peor virus que la desinformación. marzo 2020 [Click report: the worst virus is misinformation]. Retrieved from http://www.clickresearch.ec/index.php/click-report

Colectivo Reexistencias Cimarrunas, Mujeres de Asfalto y AMANDLA (2020). Manifiesto [Manifesto]. Retrieved from:

https://docs.google.com/forms/d/e/1FAlpQLSczcjrAe7_0P4-

8NkQMFN16e1ZVxICtszakUx4u2cpvJ3-JvQ/viewform

Comisión Especial para la Verdad y la Justicia (2021). Informe de la comisión especial para la verdad y la justicia respecto de los hechos ocurridos en Ecuador entre el 3 y el 16 de octubre de 2019 [Report by the special comission for truth and justice regarding the facts ocurred in Ecuador between 3 - 16 October 2019]. Quito: Defensoría del Pueblo de Ecuador.

Drury, J., Reicher, S., \& Stott, C. (2020). COVID-19 in context: Why do people die in emergencies? It's probably not because of collective psychology.

British Journal of Social Psychology, 59(3), 686-693. https://doi.org/10.1111/bjso.12393

Dusell, E. (2020). Cuando la naturaleza jaquea a la orgullosa modernidad [When nature checkmates pride modernity]. Retrieved from http://www.coha.org/cuando-la-naturaleza-jaquea-a-la-orgullosamodernidad/

Ecuador TV. (2020a). \#24DeMayo | discurso del presidente Lenín Moreno [\#24DeMayo | speech by president Lenín Moreno] [video file]. Retrieved from https://www.youtube.com/watch?v=2UbAg6vNRAE

Ecuador TV. (2020b). \#CadenaNacional. mensaje del vicepresidente Otto Sonnenholzner [\#Cadena Nacional. A message from vicepresident Otto Sonnenholzner] [video file]. Retrieved from https://www.youtube.com/watch?v=fB-s-H9Ehh0

Ecuador TV. (2020c). \#CadenaNacional | mensaje del presidente Lenín Moreno - 15/04/2020 [\#CadenaNacional | a message by president Lenín Moreno] [video file]. Retrieved from https://www.youtube.com/watch?v=pdMDATUqlfc

Ecuador TV. (2020d). \#CadenaNacional | mensaje del vicepresidente de la república, Otto Sonnenholzner. 17-04-2020 [\#Cadena Nacional. A message from the vicepresident of the Republic, Otto Sonnenholzner. 1704-2020] [video file]. Retrieved from https://www.youtube.com/watch?v=5mHPCxr1vdU\&t=292s

El Comercio. (2020, May 21). "Hay movimientos políticos que tienen una posición de generar caos", dice Roldán frente a anuncios de protestas 
["There are political movements with a position to generate chaos", says Roldán at the face of announced protests]. El Comercio. Retrieved from https://www.elcomercio.com/actualidad/movimientos-politicos-protestasgobierno-roldan.html

El Universo. (2020). El duelo, una oportunidad de crecimiento y reconstrucción [Griefing, an oportunity for growth and reconstruction]. El Universo.

Retrieved from www.eluniverso.com/entretenimiento/2020/04/13/nota/7812261/duelooportunidad-crecimiento-reconstruccion

Erikson, S. (2020). Pandemics show us what government is for. Nature Human Behaviour, 4(May), 441-442. https://doi.org/10.1038/s41562-020-0871-4

Fairgclough, N. (2013). Critical discourse analysis: The critical study of language. New York: Routledge.

Fine, M. (2012). Troubling calls for evidence: A critical race, class and gender analysis of whose evidence counts. Feminism and Psychology, 22(1), 319. https://doi.org/10.1177/0959353511435475

Flores, M; Huerta-Charles, L. \& Bravo, O.A. (2020). Las ciencias sociales: al otro lado del discurso neoliberal [Social sciences: at the other side of the neoliberal discourse]. Bogotá: Universidad de Tijuana y Universidad ICESI.

Forster, T., Kentikelenis, A., Reinsberg, B., Stubbs, T., \& King, L. (2019). How structural adjustment programs affect inequality: A disaggregated analysis of IMF conditionality, 1980-2014. Social Science Research, 80, 83-113. https://doi.org/https://doi.org/10.1016/j.ssresearch.2019.01.001

Góralska, M. (2020). Anthropology from Home. Advice on Digital Ethnography for the Pandemic Times. Anthropology in Action, 27(1), 46-52 doi:10.3167/aia.2020.270105

Greenhalgh, T., \& Russell, J. (2009). Evidence-based policymaking: A critique. Biology and Medicine, 52(2), 304-318

Grondona-Opazo, G., \& Rodríguez, M. (2020). Dimensión ética y política en la psicología comunitaria : análisis de la formación académica y la praxis profesional en Ecuador [Ethical and political dimensions in Community Psychology: An analysis of academic training and professional praxis in Ecuador]. Psykhe, 29(1), 1-17.

https://doi.org/https://doi.org/10.7764/psykhe.29.1.1224

Hallo, A., Rojas, A., \& Hallo, C. (2020). Perspective from Ecuador, the second country with more confirmed cases of coronavirus disease 2019 in South America: A review. Cureus, 12(3), e7452. https://doi.org/doi:10.7759/cureus.7452

Harrison, H., Birks, M., Franklin, R., \& Mills, J. (2017). Case study research: Foundations and methodological orientations. Forum Qualitative 
Sozialforschung, 18(1). https://doi.org/10.17169/fqs-18.1.2655

INEC. (2020). Encuesta nacional de empleo, desempleo y subempleo (ENEMDU), diciembre 2019. pobreza y desigualdad. Quito, 16 de enero de 2020 [National survey on employment, unemployment and underemployment (ENEMDU), December 2019. Porvery and inequality. Quito, 16 th January 2020]. Retrieved from https://www.ecuadorencifras.gob.ec/documentos/webinec/POBREZA/2019/Diciembre-2019/Boletin tecnico de pobreza diciembre 2019_d.pdf

Jetten, J., Reicher, S. D., Haslam, S. A., \& Cruwys, T. (2020). The need for a social identity analysis of covid-19. In J. Jetten, S. D. Reicher, S. A. Haslam, \& T. Cruwys (Eds.) Toghether appart: The psychology of COVID19 (pp. 7-19).Sage.

Kagan, C., Burton, M., Duckett, P., Lawthom, R., \& Siddiquee, A. (2019). Critical Community Psychology: Critical action and social change. Abingdon, UK: Routledge.

Klein, N. (2007). The shock doctrine: The rise of disaster capitalism. London: Allen Lane.

Long, G. (2020). How Ecuador descended into covid-19 chaos. Retrieved from https://cepr.net/how-did-ecuador-spiral-into-its-covid-19-nightmare/

Mackworth-Young, C. R. ., Chingono, R., Mavodza, C., McHugh, G., Tembo, M., Dziva Chikwari, C., ... Ferrand, R. A. (2020). 'Here, we cannot practice what is preached': Early qualitative learning from community perspectives on Zimbabwe's response to covid-19. Bulletin of the World Health Organization. Retrieved from: https://www.who.int/bulletin/online_first/20260224.pdf

Madison, S. (2019). Critical ethnography: Method, ethics, and performance. Thousand Oaks, CA: SAGE.

Marmot, M. (2020). Society and the slow burn of inequality. The Lancet, 395(10234), 1413-1414. https://doi.org/https://doi.org/10.1016/S01406736(20)30940-5

Martin-Baró, I. (1994). Writings for a liberation psychology. Cambridge, MA, USA: Harvard University Press.

Montero, M., Sonn, C., \& Burton, M. (2017). Community psychology and liberation psychology: A creative synergy for an ethical and transformative praxis. In M. A. Bond, I. Serrano-García, \& C. B. Keys (Eds.), Handbook of community psychology: Theoretical foundations, core concepts, and emerging challenges (Vol. 1, pp. 149-167). American Psychological Association. https://doi.org/10.1037/14953-007

Moser, C., \& Peek, O. (2020). COVID-19 in Guayaquil: From global notoriety to 
family responses. Retrieved from https://www.iied.org/covid-19-guayaquilglobal-notoriety-family-responses

Napier, A. D., Ancarno, C., Butler, B., Calabrese, J., Chater, A., Chatterjee, H., ... Woolf, K. (2014). Culture and health. The Lancet, 384(9954), 1607-39.

Notimundo. (2019). La aprobación a la gestión de Lenín Moreno cayó al 12\% durante las protestas, según cedatos [The aproval of Lenín Moreno's administration droped to $12 \%$ during protests, according to cedatos]. Retrieved from https://notimundo.com.ec/la-aprobacion-a-la-gestion-delenin-moreno-cayo-al-12-durante-las-protestas-segun-cedatos/

Ntontis, E., \& Rocha, C. (2020). Solidarity. In J. Jetten, S. D. Reicher, S. A. Haslam, \& T. Cruwys (Eds.), Toghether appart: The psychology of COVID19 (pp. 102-106). Sage.

Parker, I. (2007). Revolution in Psychology: Alienation to Emancipation. London, UK: Pluto Press.

Patel, P. (2020). The health-related determinants of politics. The Lancet, 395(10238), 1694. https://doi.org/10.1016/S0140-6736(20)30555-9

Pavón-Cuéllar, D. (2020). Michel Foucault, su inconfesado marxismo y su crítica de la psicología [Michel Foucault, his unconfessed Marxism and his critique of psychology]. Athenea Digital, 20(1), 1-23.

Stevens, A. (2020). Governments cannot just 'follow the science' on covid-19. Nature Human Behaviour, 41562. https://doi.org/10.1038/s41562-0200894-x

Talak, A. (2014). Las explicaciones en psicología [Explanations in psychology]. Buenos Aires. Argentina: Prometeo.

The Rising Majority. (2020). Movement building in the time of the coronavirus: A rising majority teach-in [video file]. Retrieved from https://www.youtube.com/watch?v=xUP0swVDmtg

UN News. (2019). UN rights chief calls for dialogue to prevent conflict, ease social unrest in Ecuador. Retrieved from https://news.un.org/en/story/2019/11/1052481

Van Bavel, J., Baicker, K., Boggio, P. S., Capraro, V., Cichocka, A., Cikara, M., ... Willer, R. (2020). Using social and behavioural science to support covid19 pandemic response. Nature Human Behaviour, 4, 460-471. https://doi.org/10.1038/s41562-020-0884-z

Varghese, S. (2020, May 21). Why has Kerala been so successful in tackling coronavirus? NewsStatesman. Retrieved from https://www.newstatesman.com/world/asia/2020/05/kerala-coronaviruscases-response-india-KK-Shailaja 
Wiesenfeld, E. (2016). Trascendiendo confines disciplinares: continuidad, psicología comunitaria crítica y psicología social comunitaria al revés [Transcending disciplinary boundaries: Continuity, critical community psychology, and backwards community social psychology. Revista Interamericana de Psicologia, 50(1), 4-13.

Wolff, J. (2018). Ecuador after Correa: the struggle over the "citizens' revolution". Revista de Ciencia Política, 38(2), 281-302. https://doi.org/10.4067/s0718-090x2018000200281

Žižek, S. (2020). Pandemic! Covid-19 shakes the world. NY, USA: OrBooks. 